\title{
TINGKAT PENCAPAIAN ASPEK PERKEMBANGAN ANAK USIA 5-6 TAHUN BERDASARKAN STANDAR NASIONAL PENDIDIKAN ANAK USIA DINI
}

\author{
Umar Sulaiman \\ Fakultas Tarbiyah dan Keguruan, UIN Alauddin Makassar \\ e-mail: umartarbiyah72@yahoo.co.id \\ Nur Ardianti \\ Jurusan Pendidikan Islam Anak Usia Dini \\ Fakultas Tarbiyah dan Keguruan, UIN Alauddin Makassar \\ e-mail: nurardianti80@gmail.com \\ Selviana \\ Jurusan Pendidikan Islam Anak Usia Dini \\ Fakultas Tarbiyah dan Keguruan, UIN Alauddin Makassar \\ e-mail: anandaselvi48@gmail.com
}

\begin{abstract}
Abstrak
Penelitian ini bertujuan untuk mengetahui gambaran tingkat pencapaian perkembangan anak usia 5-6 tahun berdasarkan Standar Pendidikan Nasional Pendidikan Anak Usia Dini (PAUD) dan melakukan deteksi dini terhadap hambatan pencapaian perkembangannya. Penelitian ini merupakan penelitian kualitiatif jenis deskriptif dengan subjek penelitian dua anak yang berusia 5 tahun dan usia 6 tahun. Data dikumpulkan menggunakan observasi, wawancara dan beberapa rangkaian stimulus untuk mendukung munculnya respon pencapaian perkembangan yang hendak diukur mulai aspek nilai agama-moral, fisik-motorik, kognitif, bahasa, sosialemosional, sampai pada aspek seni. Data yang sudah terkumpul dianalisis menggunakan analisis deskriptif. Hasil penelitian menunjukkan bahwa dari kedua subjek masih ada beberapa indikator pencapaian yang belum dan lebih banyak yang sudah tercapai dari semua aspek perkembangan anak usia dini. Keberhasilan dari pencapaian standar tingkat pencapaian perkembangan anak usia dini dapat disebabkan oleh pola asuh yang diberikan oleh orangtua kepada anak, pemberian stimulasi yang sesuai dengan tingkat usia dan perkembangan anak serta faktorfaktor pendukung yang bersumber dari lingkungan sekitar anak
\end{abstract}

Kata Kunci: Aspek Perkembangan, Anak Usia Dini, Standar Nasional Pendidikan

\begin{abstract}
This study aims to describe the level of achievement of the development of children aged 5-6 years based on the National Education Standards for Early Childhood Education (PAUD) and early detection of barriers to achieving development. This research is a descriptive qualitative research with two children aged 5 years and 6 years old. Data was collected using observations, interviews and a series of stimuli to support the emergence of responses to developmental achievements to be measured from aspects of religious-moral, physical-motoric, cognitive, language, social-emotional, to aspects of art. The collected data was analyzed using descriptive
\end{abstract}


analysis. The results of the study show that of the two subjects there are still some indicators of achievement that have not been and more have been achieved from all aspects of early childhood development. The success of achieving the standard level of achievement of early childhood development can be caused by parenting provided by parents to children, providing stimulation in accordance with the age and development of children and supporting factors sourced from the environment around the child

Keywords: Developmental Aspects, Early Childhood, National Education Standards

\section{PENDAHULUAN}

Perkembangan adalah pola perubahan yang dimulai sejak masa konsepsi dan berlanjut sepanjang kehidupan. Perkembangan berkaitan dengan hal-hal yang bersifat fungsional, sedangkan pertumbuhan bersifat biologis. Menurut Hurlock dalam (Sit, 2015: 3) pada dasarnya dua proses perkembangan yaitu pertumbuhan atau evolusi dan kemunduran atau involusi terjadi secara serentak dalam kehidupan manusia.

Santrock dalam Sit (2015: 5) menyatakan perkembangan anak usia dini mencakup aspek perkembangan fisik, kognitif, sosial-emosional, konteks sosial, moral, bahasa, identitas diri, dan gender. Menurut Wulandari dkk (2016: 48) usia 06 tahun adalah usia yang sangat menentukan dalam pembentukan karakter baik sikap, perilaku, dan kepribadian seorang anak di masa depan. Masa balita juga sebagai periode emas bagi orangtua untuk mengembangkan potensi anak secara optimal. Pada masa balita hampir seluruh sel-sel otak berkembang pesat. Tidak ada orang yang paling berarti dalam kehidupan seorang balita selain orangtuanya yang dapat memenuhi segala pertumbuhan dan perkembangannya.

Menurut Wulandari, dkk (2016: 48) mengatakan bahwa kemampuan orangtua dalam memenuhi kebutuhan akan asuh, asih, dan asah akan mempengaruhi mutu kepribadian anak di kemudian hari. Pertumbuhan dan perkembangan anak dipengaruhi oleh banyak faktor diantaranya pendidikan ibu, pekerjaan ibu, pendidikan bapak, stimulasi perkembangan dan faktor lingkungan dari anak. Meadow dalam Wulandari dkk (2016: 48) menyatakan bahwa lingkungan akan mempengaruhi anak dalam berbagai hal, antara lain akan berpengaruh terhadap bagaimana seorang anak berkembang dan belajar dari lingkungan.

Menurut Harahap (2017: 1-2) mengatakan bahwa pentingnya pendidikan diberikan pada anak usia dini (AUD) terdapat dalam Undang-undang Sisdiknas Nomor 20 Tahun 2003 Peraturan Pemerintah tentang Pendidikan Anak Usia Dini Pasal 1 ayat 1, dinyatakan bahwa "Pendidikan Anak Usia Dini disebut juga dengan pendidikan anak usia dini (PAUD) adalah suatu upaya pembinaan yang ditujukan kepada anak sejak lahir sampai berusia enam tahun yang dilakukan melalui pemberian rangsangan pendidikan untuk membantu pertumbuhan dan 
perkembangan jasmani dan rohani agar anak memiliki kesiapan dalam memasuki pendidikan lebih lanjut".

Adapun aspek perkembangan anak usia dini terdiri dari beberapa aspek. Pertama, perkembangan moral dan agama. Pada aspek perkembangan agama dan moral anak usia 5-6 tahun memiliki beberapa indikator pencapaian perkembangan yaitu mengenal agama yang dianut, meniru gerakan ibadah dengan urutan yang benar, mengucapkan salam dan membalas salam. Kedua, perkembangan fisikmotorik. Perkembangan fisik motorik terbagi atas tiga yaitu motorik kasar, motorik halus dan kesehatan dan perilaku keselamatan. Ketiga, aspek perkembangan kognitif memiliki tiga bagian yaitu belajar dan pemecahan masalah, berfikir logis, dan berpikir simbolik. Keempat, aspek perkembangan bahasa memiliki dua bagian yaitu memahami bahasa dan mengungkapkan bahasa. Kelima, perkembangan sosialemosional. Terbagi atas 3 yaitu kesadaran diri, rasa tanggung jawab untuk diri sendiri dan orang lain.

Berbagai aspek perkembangan dalam diri anak usia dini perlu untuk diamati melalui program deteksi dini dan stimulasi perkembangan. Deteksi dini tumbuh kembang anak adalah kegiatan yang dilakukan untuk menemukan adanya penyimpangan pertumbuhan dan perkembangan pada anak pra sekolah. Dengan menemukan penyimpangan tumbuh kembang sejak awal, maka dapat dilakukan intervensi yang tepat sejak dini untuk mengatasi penyimpangan tersebut. Namun bila penyimpangan terlambat diketahui, maka intervensi akan lebih sulit untuk dilakukan dan hal ini tentunya akan mempengaruhi tumbuh kembang anak (Fazrin, 2018: 7).

Deteksi dini dilakukan pada anak untuk mengetahui tingkat pencapaian anak. Oleh karena itu perlu dilakukan deteksi dini mengenai gambaran stimulasi yang diberikan orang tua kepada anak agar setiap aspek perkembangan bisa tercapai secara normal dan untuk memahami apa-apa yang harus dikembangkan anak terhadap tingkat pencapaian aspek perkembangan.

\section{METODE PENELITIAN}

Penelitian ini merupakan penelitian kualitatif jenis deskriptif dengan subjek penelitian dua anak rentang usia 5-6 tahun. Tujuan penelitian ini untuk mengetahui: tingkat pencapaian perkembangan anak usia 5-6 tahun. Subjek yang dipilih dengan kriteria; (1) anak mudah diajak bercengkrama; (2) anak usia rentang 5-6 tahun; (3) orang tua menerima peneliti dengan baik; dan (4) mudah dijangkau.

Data dikumpulkan menggunakan observasi, wawancara dan beberapa rangkaian stimulasi yang diberikan kepada anak, dan tingkat pencapaian dari beberapa indikator yang sudah tercapai dengan baik dan beberapa indikator yang belum tercapai masih perlu distimulasi oleh orang tua dan guru di sekolah. 


\section{HASIL DAN PEMBAHASAN}

Hasil penelitian yang dilakukan pada dua orang subjek tersebut dijabarkan dalam pencapaian pada aspek-aspek perkembangan sebagai berikut:

\section{Aspek Agama dan Moral}

Tingkat pencapaian perkembangan aspek nilai agama dan moral dapat dilihat dari delapan indikator. (1) mengenal agama yang dianut; (2) meniru gerakan ibadah dengan urutan yang benar; (3) mengucapkan salam dan membalas salam; (4) mengucapkan doa sebelum dan sesudah makan; (5) mengerjakan ibadah; (6) berperilaku jujur, penolong, sopan, hormat, dan sportif; (7) menjaga kebersihan diri dari lingkungan; (8) mengetahui hari besar agama menghormati (toleransi) agama orang lain.

Berdasarkan hasil penelitian dari dua subjek yaitu $\mathrm{N}$ dan $\mathrm{A}$, maka didapatkan gambaran perkembangan nilai agama dan moral yang berbeda-beda tiap subjek penelitian. Indikator pertama, kedua subjek sudah mengenal apa yang wajib dilakukan seperti shalat, puasa, dan beramal. Indikator kedua, A hanya mampu menirukan gerakan rukuk dan sujud sedangkan $\mathrm{N}$ yang sudah mampu menirukan semua gerakan shalat. Indikator ketiga, A dan $\mathrm{N}$ sudah mampu mengucapkan salam serta membalas salam ketika masuk dan keluar ruangan. Indikator keempat, A dan $\mathrm{N}$ sudah mampu membaca doa sebelum dan sesudah makan namun baru lakukan hanya ketika disuruh orang tua atau gurunya saja. Indikator kelima, N hanya mampu mengikuti gerakan shalat namun tidak semua bacaan dia hafal, anak hanya mampu mengikuti gerakan dan bacaan Al-Fatihah. Untuk indicator berperilaku jujur, penolong, sopan, hormat dan sportif, $\mathrm{N}$ termasuk anak yang jujur. Ketika $\mathrm{N}$ ditanya sudah makan, $\mathrm{N}$ menjawab dengan ucapan sopan. $\mathrm{N}$ juga suka menolong teman yang kesusahan dan hormat/patuh kepada orang tuanya. Kedua subjek membersihkan diri sendiri ketika hendak bermain di luar rumah dan mencuci tangan ketika masuk ke rumah walau masih perlu pantauan orangtuanya. Indikator kedelapan, $\mathrm{N}$ belum mengetahui hari besar agama dan menghormati (toleransi) agama orang lain.

\section{Aspek Fisik-Motorik}

Ada dua aspek perkembangan fisik-motorik yang harus dicapai yaitu aspek motorik kasar dan motorik halus. Dimana pada aspek motorik kasar dapat dilihat dari delapan indikator yaitu (1) naik turun tangga; (2) melompat; (3) berlari; (4) melakukan gerakan tubuh secara terkoordinasi untuk melatih kelenturan, keseimbangan, dan kelincahan; (5) melakukan koordinasi gerakan mata-kakitangan-kepala dalam menirukan tarian atau senam; (6) melakukan permainan fisik dengan aturan; (7) terampil menggunakan tangan kanan dan kiri; (8) melakukan kegiatan kebersihan diri.

Berdasarkan hasil penelitian dari dua subjek, A sudah mampu naik turun tangga sebanyak 3 kali, melompat dengan tinggi 1 meter dan mampu berlari 
mengelilingi kelas 1-3 kali putaran. Sedangkan N sudah mampu berjalan sambil jinjit dengan beberapa langkah dan hitungan 1-10, menirukan gerakan tarian namun dengan mengikuti gerakan orang lain dan terlebih dahulu diberikan contoh, melemparkan batu sesuai dengan aba-aba yang diberikan, tangan kanan digunakan untuk memegang sendok dan kiri digunakan untuk mencuci kotoran (buang air). Untuk indikator kedelapan, $\mathrm{N}$ sudah mampu mandi sendiri akan tetapi belum pernah mandi sendiri karena setiap hari anak dimandikan oleh orang ibunya karena orang tuanya terlalu memanjakan anaknya. Sedangkan untuk indikator motorik halus terbagi atas: (1) menggambar tanda plus dan silang; (2) menggunting; (3) menggambar sesuai gagasannya; (4) meniru bentuk; (5) melakukan eksplorasi dengan berbagai media dan kegiatan; (6) menggunakan alat tulis dan alat makan dengan benar; (7) menggambar sesuai dengan pola (8) menempel gambar dengan tepat; (9) mengekspresikan diri melalui gerakan menggambar secara rinci. Dari hasil penelitian, didapatkan gambaran perkembangan nilai fisik-motorik halus sebagai berikut yaitu A sudah mencapai indikator 1-4. N juga sudah mencapai indicator 1-4 sedangkan untuk indicator ke-5, N belum terlalu paham dalam memilih media yang akan digunakan. Untuk indikator 6-9, N sudah mampu melakukannya.

Ada sembilan indikator yang menunjang perkembangan motorik anak terkait kesehatan dan perilaku keselamatan yaitu (1) berat badan sesuai tingkat usia; (2) tinggi badan sesuai standar usia; (3) berat badan sesuai dengan standar tinggi badan; (4) lingkar kepala sesuai tingkat usia; (5) menutup hidung dan mulut (misal ketika batuk dan bersin); (6) membersihkan dan membereskan tempat bermain; (7) mengetahui situasi yang membahayakan diri; (8) memahami tata cara menyeberang;; (9) mengenal kebiasaan buruk bagi kesehatan (rokok, minuman keras. Berdasarkan hasil penelitian maka didapatkan gambaran sebagai berikut yaitu subjek $\mathrm{N}$ sudah memenuhi beberapa indikator pencapaian yang terkait dengan kesehatan dan perilaku keselamatan.

Untuk indikator pertama, Menurut Kementerian Kesehatan Republik Indonesia, berat badan ideal anak perempuan usia 6 tahun adalah 11, 6-27,7 kg. Berat badan $\mathrm{N}$ memiliki berat badan $15 \mathrm{~kg}$. Hal ini menunjukkan bahwa N memiliki berat badan ideal. Untuk indikator kedua, tinggi badan anak perempuan usia 6 tahun yaitu 93-120,4 cm. N memiliki tinggi $98 \mathrm{~cm}$. Ini menunjukkan bahwa tinggi badan $\mathrm{N}$ telah memenuhi indikator pencapain yang terkait tentang tinggi badan sesuai tingkat usia. Untuk indikator ketiga, subjek $\mathrm{N}$ memiliki berat badan sesuai dengan standar tinggi badan. Untuk indikator keempat, lingkar kepala anak perempuan normal usia 6 tahun adalah 45,4-54 cm. Hal ini berarti N sudah memiliki lingkar kepala sesuai dengan tingkat usia karena ukuran lingkar kepala $\mathrm{N}$ yaitu 49,7 cm. Untuk indikator kelima, $\mathrm{N}$ menutup hidung saat bersin karena takut menular bakteri ke teman yang lain. Untuk indikator keenam $\mathrm{N}$ mampu membereskan tempat mainan sendiri agar kelihatan bersih dan rapi. Untuk indikator ketujuh, ketika teman $\mathrm{N}$ membakar petasan, $\mathrm{N}$ akan pergi jauh untuk menghindari bahaya petasan. Untuk indikator 
kedelapan, anak melambaikan tangan dan melirik kiri dan kanan untuk memastikan bisa menyeberang atau tidaknya. Selanjutnya indikator kesembilan, ketika melihat orang merokok anak akan berusaha untuk jauh/menghindari dari asap yang menyebar kemana-mana.

\section{Aspek Kognitif}

Tingkat pencapaian perkembangan anak dalam aspek perkembangan kognitif terbagi atas enam indikator untuk belajar dan pemecahan masalah yaitu (1) menunjukkan aktivitas yang bersifat eksploratif dan menyelidik (seperti apa yang terjadi ketika air ditumpahkan); (2) memecahkan masalah sederhana dalam kehidupan sehari-hari dengan cara yang fleksibel dan diterima sosial; (3) menerapkan pengetahuan atau pengalaman dalam konteks yang baru; (4) menunjukkan sikap kreatif dalam menyelesaikan masalah (ide, gagasan, di luar kebiasaan); (5) mengenal benda berdasarkan fungsi; (6) menyebutkan berbagai nama makanan dan rasanya.

Berdasarkan hasil penelitian didapatkan gambaran yaitu untuk indikator pertama sampai keempat, subjek $\mathrm{N}$ sudah mencapai semua indikator seperti mengambil lap/tissue ketika air tumpah agar tidak jatuh karena licin, menyiapkan berbagai perlengkapan seperti obat dan alat periksa dokter dan N seketika meminta maaf ketika melakukan kesalahan terhadap temannya. Sama halnya dengan subjek A, sudah mencapai indikator lima dan enam yaitu ketika ibu A memperlihatkan panci, A tahu bahwa itu fungsinya untuk memasak nasi atau sayur, piring untuk makan dan lain-lain. A juga mampu menyebutkan nama makanan seperti keju yang rasanya asin.

Untuk berpikir logis, terdapat delapan indikator yaitu; (1) mengenal perbedaan berdasarkan ukuran: "lebih dari"; "kurang dari"; dan "paling/ter"; 2) menunjukkan inisiatif dalam memilih tema permanian (seperti: "ayo kita bermain pura-pura seperti burung"; (3) menyusun perencanaan kegiatan yang akan dilakukan; (4) mengenal sebab-akibat tentang lingkungannya (angin tertiup menyebabkan daun bergerak, air dapat menyebabkan sesuatu menjadi basah); (5) mengklasifikasikan benda berdasarkan warna, bentuk, dan ukuran "tiga variasi”; (6) mengklasifikasikan benda yang lebih banyak ke dalam kelompok yang sama atau kelompok yang sejenis, atau kelompok berpasangan yang lebih dari "dua variasi"; (7) mengenal pola ABCD-ABCD; (8) mengurutkan benda berdasarkan ukuran dari paling kecil ke paling besar atau sebaliknya. Berdasarkan hasil penelitian didapatkan gambaran yaitu dari delapan indikator hanya dua indikator yang belum dicapai oleh $\mathrm{N}$ yaitu anak belum mampu mengklasifikasikan 2-3 variasi dengan baik, sehingga masih perlu bantuan orang tua/guru.

Untuk berpikir simbolik, ada lima indikator pencapaian yaitu (1) menyebutkan lambang bilangan 1-10; (2) menggunakan lambang bilangan untuk menghitung; (3) mencocokkan bilangan dengan lambang bilangan; (4) mengenal berbagai macam 
lambing huruf vokal dan konsonan; (5) mempresentasikan berbagai macam dalam bentuk gambar atau tulisan (ada benda pensil yang diikuti tulisan dan gambar pensil). Berdasarkan hasil penelitian didapatkan gambaran yaitu kedua subjek sudah mampu melakukan semua indikator dengan baik.

\section{Aspek Perkembangan Bahasa}

Tingkat pencapaian perkembangan anak dalam aspek perkembangan bahasa terbagi atas 2 yaitu memahami bahasa dan mengungkapkan bahasa. Dalam hal memahami bahasa, terdapat tujuh indikator perkembangan yaitu; (1) menyimak perkataan orang lain, (2) mengenal suara-suara hewan/benda yang ada disekitarnya; (3) menjawab pertanyaan sesuai pertanyaan; (4) mengerti beberapa perintah secara bersamaan; (5) mengulang kalimat yang lebih kompleks; (6) memahami aturan dalam suatu permanian; (7) senang dan menghargai bacaan. Berdasarkan hasil didapatkan gambaran yaitu A sudah mampu menyimak perkataan orangtua dan mengambil apa yang disuruhkan oleh ibunya sesuai dengan keinginan orangtuanya. A mampu menirukan suara yang ada disekitanya seperti suara kucing. Ketika diberi pertanyaan, A akan menjawab menjawab dengan benar tanpa diberitahu oleh orang yang ada didekatnya. Ketika $\mathrm{N}$ disuruh duduk, maka $\mathrm{N}$ akan duduk tanpa harus dipakasa. $\mathrm{N}$ mulai lancar mengulang kalimat yang didengarnya meskipun 1-2 kalimat saja. N ketika hendak membaca Al-Quran, N akan merasa senang sambil mendengar dan belajar dengan baik.

Untuk mengungkapkan bahasa, terdapat enam indicator yaitu; (1) menjawab pertanyaan yang lebih kompleks; (2) menyebutkan kelompok gambar yang memiliki bunyi yang sama; (3) berkomunikasi secara lisan, memiliki pembendaharaan kata, serta mengenal simbol-simbol untuk persiapan membaca, menulis serta berhitung; (4) menyususn kalimat sederhana dalam struktur lengkap "pokok-kalimat-predikatketerangan"; (5) memiliki lebih banyak kata-kata untuk mengekspresikan ide pada orang lain; (6) melanjutkan sebagian cerita/dongeng yang telah didengarkan menunjukkan pemahaman konsep-konsep dalam buku cerita. Berdasarkan hasil penelitian, dari keenam indikator hanya ada satu indikator yang belum dicapai oleh $\mathrm{N}$ yaitu indikator belum paham dalam menyusun struktur.

\section{Aspek Perkembangan Sosial-Emosional}

Pada tahapan perkembangan sosial emosional terdapat tiga indikator yaitu; (1) menujukkan rasa percaya diri; (2) menjaga diri sendiri dari lingkungan; (3) mau berbagi, menolong, dan membantu teman. Berdasarkan hasil penelitian dari tiga indikator, A sudah berani tampil di depan dengan menunjukkan hasil karyanya sendiri dengan rasa percaya diri, ketika di sekolah A mencuci peralatan makananya sendiri sesuai instruksi yang diberikan oleh gurunya, A mulai berbagi, menolong dan membantu teman sesuai kemampuannya sendiri.

Terdapat tiga indikator dalam hal kesadaran diri yaitu (1) memperlihatkan kemampuan diri untuk menyesuaikan dengan situasi; (2) memperlihatkan kehati- 
hatian kepada orang yang belum dikenal "menumbuhkan kepercayaan pada orang dewasa yang tepat; (3) mengenal perasaan sendiri dan mengelolanya secara wajar "mengendalikan diri secara wajar". Dari hasil penelitian masih ada satu indikator yang belum dicapai oleh $\mathrm{N}$ yaitu mengenal perasaan sendiri dan mengelolanya secara wajar.

Terdapat empat indikator untuk rasa tanggung jawab untuk diri sendiri dan orang lain yaitu; (1) tahu akan haknya; (2) mentaati aturan kelas "kegiatan dan aturan"; (3) mengatur diri sendiri; (4) bertanggung jawab atas perilakunya untuk kebaikan diri sendiri. Dari hasil penelitian didapatkan gambaran yaitu $\mathrm{N}$ belum mampu mengatur diri sendiri. $\mathrm{N}$ masih perlu bantuan dari orang tua/guru karena $\mathrm{N}$ biasa melakukan kesalahan.

Terdapat sembilan indikator untuk perilaku prososial yaitu (1) bermain dengan teman sebaya; (2) mengetahui perasaan temannya dan merespon secara wajar; (3) berbagi dengan orang lain; (4) menghargai hak/pendapat/karya orang lain; (5) menggunakan cara yang diterima secara sosial dalam menyelesaikan masalah "menggunakan pikiran untuk menyelesaikan masalah"; (6) bersikap kooperatif dengan teman; (7) menunjukkan sikap toleran; (8) mengekspresikan emosi yang sesuai dengan kondisi yang ada "senang-sedih-antusias"; (9) mengenal tata krama dan sopan santun sesuai dengan nilai sosial budaya setempat. Berdasarkan hasil penelitian dari sembilan indikator, terdapat satu indikator yang belum tercapai yaitu indikator kelima dimana $\mathrm{N}$ masih perlu bantuan dari orangtua dalam menyelesaikan masalah. Sedangkan untuk indikator yang lain sdh tercapai.

\section{Aspek Perkembangan Seni}

Tingkat pencapaian perkembangan dalam aspek perkembangan seni terbagi atas dua bagian yaitu anak mampu membedakan antara bunyi dan suara dan kedua tertarik dengan kegiatan atau karya seni. Untuk bagian pertama membedakan antara bunyi dan suara, terdapat dua indikator yaitu; (1) anak bersenandung atau bernyanyi sambil mengerjakan sesuatu; (2) memainkan musik/instrumen/benda bersama teman. Untuk bagian kedua terbagi atas dua indikator yaitu (1) senang mendengarkan berbagai macam musik atau lagu kesukaannya; (2) bernyanyi sendiri. Berdasarkan hasil penelitian untuk indikator pertama, kedua subjek sangat senang ketika diputarkan lagu kesukaannya. Untuk indikator kedua, kedua subjek sangat suka bernyanyi sendiri.

Berdasarkan hasil penelitian dalam membedakan antara bunyi dan suara, $\mathrm{N}$ kadang-kadang bersenandung dengan lagu walau hanya sepotong-sepotong ketika melakukan sesuatu. $\mathrm{N}$ belum bisa memainkan alat musik walau dengan bantuan orang tua/guru. Dalam hal tertarik dengan kegiatan atau karya seni, terdapat enam indikator pencapaian, yaitu (1) menyanyikan lagu dengan sikap yang benar; (2) menggunakan berbagai macam alat musik tradisional maupun alat musik lain untuk menirukan suatu irama atau lagu tertentu; (3) bermain drama sederhana; (4) 
menggambar berbagai macam bentuk yang beragam; (5) melukis dengan berbagai cara dan objek; (6) membuat karya seperti bentuk sesungguhnya dengan berbagai bahan seperti kertas, plastisin, dan balok. Berdasarkan hasil penelitian dalam hal tertarik dengan kegiatan atau karya seni, subjek $\mathrm{N}$ bernyanyi dengan sikap yang benar sesuai dengan lagu yang dinyanyikan. $\mathrm{N}$ belum bisa menggunakan alat tradisional. $\mathrm{N}$ mampu memainkan peran-peran seperti dokter-dokter. $\mathrm{N}$ sudah mampu menggambar mikrofon walau dengan bantuan guru. $\mathrm{N}$ melukis dengan baik tapi dengan bantuan orang lain dan $\mathrm{N}$ mampu membuat bentuk buah seperti papaya dengan baik tanpa bantuan orang lain.

\section{PEMBAHASAN}

Ibu adalah pendidik pertama, utama dan kodrat. Perkembangan anak bukan semata-mata merupakan hasil proses belajar di sekolah. Melainkan ditunjang dari peran seorang ibu di rumah. Peran seorang ibu terhadap anak terasa sekali bilamana didukung oleh latar belakang pendidikan yang memadai. Karena keberhasilan pendidikan anak tidak semata-mata hanya ditentukan oleh sekolah saja. Anak lahir dalam pemeliharaan seorang ibu dan dibesarkan di dalam keluarga. Anak menyerap norma-norma pada anggota keluarga, baik ayah ibu maupun kanak-kanaknya (Filtri, 2018:169-170).

Tingkat pendidikan yang dialami seorang ibu berpengaruh terhadap pengetahuan seorang ibu, keyakinan, nilai, dan tujuan tentang pengasuhan, sehingga berbagai perilaku ibu berkaitan secara tidak langsung dengan prestasi sekolah anak-anak. Dengan demikian, peserta didik yang orangtuanya apalagi ibu memiliki tingkat pendidikan yang lebih tinggi mungkin memiliki hal untuk kesempurnaannya belajar, keyakinan akan kemampuan yang lebih positif, orientasi kerja yang kuat, dan mereka mungkin menggunakan strategi belajar yang lebih efektif daripada anak-anak dengan orangtua khususnya ibu yang memiliki tingkat pendidikan lebih rendah (Filtri, 2018: 169-170).

Perkembangan nilai agama dan moral, A sudah mencapai semua indikator dan $\mathrm{N}$ juga sudah berkembang dengan baik meskipun masih ada beberapa yang belum mampu dilakukannya dalam aspek perkembangan nilai agama yaitu; mengetahui hari besar agama menghormati, toleransi agama orang lain. $\mathrm{N}$ masih perlu distimulasi oleh orangtuanya terkait dengan hari besar agama. Ibu adalah orang yang paling dekat pada anak. Dia merupakan orang yang pertama yang mengajarkan cara berbicara, cara menghitung jari ditangan, dan cara mengekspresikan rasa kasih sayang dan simpati pada orang lain.

Perkembangan motorik $\mathrm{N}$ sudah berkembang dengan baik meskipun masih ada beberapa yang belum mampu dilakukannya dalam aspek perkembangan motorik kasarnya. Keberhasilan perkembangan dari subjek tersebut dikarenakan orangtua selalu memberikan stimulasi yang tepat terkait perkembangan motorik anak dan memberikan kebebasan kepada anak untuk melakukan aktivitas yang 
diinginkan. Selain itu, pemberian gizi juga berpengaruh terhadap pertumbuhan dan perkembangan motorik anak. Berdasarkan hasil observasi, diketahui bahwa subjek $\mathrm{N}$ sudah memiliki pertumbuhan yang optimal. Hal ini disebabkan karena orangtua selalu memberikan gizi yang seimbang kepada anak. Sedangkan untuk meningkatkan perkembangan motorik anak yang belum berkembang, orang tua harus selalu memberikan berbagai kegiatan stimulasi seperti melalui bermain dan kebebasan berkreasi pada anak agar perkembangan motoriknya mudah tercapai dengan baik. Dapat pula dengan memberikan contoh kepada anak cara melakukannya seperti melompat lalu meminta anak untuk mengulang apa yang sudah dicontohkan.

Sumantri dalam (Nugraha, 2017: 330) mengatakan bahwa pembelajaran motorik halus di sekolah ialah pembelajaran yang berhubungan dengan keterampilan fisik yang melibatkan otot kecil serta koordinasi antara mata dengan tangan. Syaraf motorik halus bisa dilatih dan dikembangkan melalui kegiatan dan rangsangan yang dilakukan secara rutin dan terus menerus diantaranya seperti: bermain puzzle, menyusun balok, memasukkan benda ke dalam lubang sesuai bentuknya, membuat garis, melipat kertas, menulis dengan huruf, dan bentuk tulisan yang benar. Ketika memberikan fasilitas yang bertujuan menstimulasi perkembangan anak tersebut, maka guru perlu mengupayakannya melalui kreativitas yang dimilikinya dengan memvariasikan berbagai strategi pembelajaran yang ada di TK dalam kegiatan mengajarnya (Nugraha, 2017: 330).

Kognitif sering kali diartikan sebagai kecerdasan, daya nalar atau berpikir. Dapat dilihat dari tingkat pencapaian indikator pertama yaitu belajar dan pemecahan masalah, semua indikator telah dicapai dan pemberian stimulus oleh orang tuanya yang bagus kepada anaknya. Kognitif adalah pengertian yang luas mengenai berpikir dan mengamati sehingga muncul tingkah laku yang mengakibatkan orang memperoleh pengetahuan atau yang dibutuhkan untuk menggunakan pengetahuan (Khadijah, 2016: 32). Hal ini dapat dilihat dari tingkat pencapaian dari dua subjek seperti menerapkan pengetahuan atau pengalaman dalam konteks yang baru dan menunjukkan sikap kreatif dalam menyelesaikan masalah (ide, gagasan di luar kebiasaan) yaitu menyusun perencanaan kegiatan yang akan dilakukan dan mengurutkan benda berdasarkan ukuran paling kecil ke paling besar atau sebaliknya. Sedangkan yang ketiga yaitu mengerti beberapa perintah secara bersamaan dan memahami ataran dalam suatu permainan.

Tahap perkembangan kognitif anak sudah baku dan saling berkaitan dalam setiap urutannya. Urutan tahapan tidak dapat ditukar atau dibalik karena tahap sesudahnya melandasi terbentuknya tahap sebelumnya. Akan tetapi terbentuknya tahap tersebut dapat berubah-ubah menurut situasi sesorang. Perbedaaan antara tahap sangat besar. Karena ada perbedaan kualitas pemikiran yang lain. Meskipun demikian unsur dari perkembangan sebelumnya tetap tidak dibuang. Jadi ada kesinambungan dari tahap ke tahap lain, walaupun ada juga perbedaan yang sangat 
mencolok. Kognitif atau intelektual adalah suatu proses berfikir berupa kemampuan atau daya untuk menghubungkan suatu peristiwa dengan peristiwa lainnya serta kemampuan menilai dan mempertimbangkan segala sesuatu yang diamati dari dunia sekitar. Kognitif dapat diartikan sebagai pengetahuan yang luas daya nalar, kreatifitas atau daya cipta, kemampuan berbahasa serta daya ingat. Gabungan antara kematangan anak dengan pengaruh lingkungan disebut kognisi. Dalam kognisi anak dapat menyelesaikan masalah lingkungan sendiri (Khadijah, 2016:32).

Bahasa adalah alat komunikasi manusia dapat berbentuk tulisan, lisan atau isyarat-isyarat yang berdasarkan pada suatu sistem dari simbol. Masyarakat mengenal bahasa verbal dan non verbal. Bahasa merupakan suatu simbol untuk berkomunikasi dengan orang lain yang meliputi daya cipta dan sistem aturan. Komunikasi menjadikan anak mendapat banyak sekali kosa kata, sekaligus dapat mengekspresikan dirinya. Anak akan belajar bagaimana berpartisipasi dalam suatu percakapan dan memecahkan masalah. Perkembangan bahasa untuk anak usia dini mempunyai empat keterampilan yaitu menyimak (dengan unsur-unsur membedakan bunyi dan memahami kata atau kalimat), berbicara (dengan unsur-unsur perkembangan kosa kata, ekspresi, artikulasi, dan kejelasan), membaca (menggunakan phonics, kata bermakna, dan gabungan phonics dan kata bermakna), dan menulis (penmanship dan ekspresi). Keempat keterampilan tersebut sebetulnya merupakan satu kesatuan yang saling mendukung dan melengkapi. Setiap keterampilan berhubungan dengan proses berpikir yang mendasari bahasa (Retno, 2017: 6). Pada indikator perkembangan bahasa dapat dilihat dua subjek yang sudah mencapai semua indikator dengan baik. Dilihat dari dua tingkat pencapaian pertama yaitu; mengerti beberapa perintah, kedua menjawab pertanyaan yang lebih kompleks dan yang

Sosial emosional pada anak penting dikembangkan. Terdapat beberapa hal mendasar yang mendorong pentingnya pengembangan sosial emosional tersebut, yaitu pertama, makin kompleksnya permasalahan kehidupan di sekitar anak, termasuk di dalamnya perkembangan IPTEK yang banyak memberikan tekanan pada anak, dan mempengaruhi perkembangan emosi maupun sosial anak. Kedua, adalah penanaman kesadaran bahwa anak adalah praktisi dan investasi masa depan yang perlu dipersiapkan secara maksimal, baik aspek perkembangan emosinya maupun keterampilan sosialnya, ketiga karena rentang usia penting pada anak terbatas. Jadi, harus difasilitasi seoptimal mungkin agar tidak ada satu fase pun yang terlewatkan, keempat ternyata anak tidak bisa hidup dan berkembang dengan IQ semata, tetapi El jauh lebih dibutuhkan sebagai bekal kehidupan, kelima telah tumbuh kesadaran pada setiap anak tentang tuntutan untuk dibekali dan memiliki kecerdasan sosial emosional sejak dini. Terdapat kecenderungan yang sama di seluruh dunia, yaitu generasi sekarang lebih banyak memiliki kesulitan emosional dari pada generasi sebelumnya sehingga berdampak pada kemampuan sosialisasinya. Aspek perkembangan sosial emosional dilihat dari semua indikator anak sudah mencapai 
dengan baik. tingkat pencapaian pertama yaitu; memperlihatkan kemampuan diri yang menyesuaikan dengan situasi, kedua tahu akan haknya dan yang ketiga mengetahui perasaan temannya dan merespon secara wajar. (Suryana, 2016:229)

Menurut Djohan dalam Priyanto (2013:47) terdapat beberapa aktivitas yang umum dilakukan dalam pendidikan musik untuk anak-anak misalnya sebagai berikut: Bernyanyi, untuk membantu perkembangan anak dalam artikulasi pada keterampilan bahasa, irama, dan kontrol pernapasan. Bermain musik, membantu pengembangan dan koordinasi kemampuan motorik. Mempelajari sebuah karya musik dengan cara memainkannya dapat mengembangkan keterampilan musik serta membangun rasa percaya diri dan disiplin diri. Gerak ritmis, digunakan untuk mengembangkan jangkauan fisiologis, menggabungkan mobilitas, ketangkasan, kekuatan, keseimbangan, koordinasi, konsistensi, pola-pola keterampilan kognisi, seperti memori dan konsentrasi. Musik dapat merangsang respons relaksasi, motivasi atau pikiran, imajinasi, dan memori yang kemudian diuji dan didiskusikan secara individual ataupun kelompok. Mamfaat seni lainnya bahkan juga berdampak penting bagi orang tua, secara signifikan, aktivitas seni yang diajari oleh orang tua pada anak akan memperkuat hubungan mereka secara langsung. Cara sederhana juga bisa dimulai oleh orang tua untuk mengenalkan seni pada anak. Misalnya dengan mengajak mereka ke meseum dan galeri seni untuk menstimulasi rasa penasaran anak. Dapat dilhat dari beberapa indikator yang dicapai anak, tingkat pencapaian pertama yaitu, anak bersenangdung atau bernyanyi sambil mengerjakan sesuatu, kedua menyanyikan lagu dengan sikap yang benar.

\section{SIMPULAN}

Berdasarkan hasil penelitian ini menggambarkan deskripsi tingkat pencapaian perkembangan kedua subjek. Penelitian mulai dari aspek nilai agama dan moral, Fisik motorik, kognitif, bahasa, sosial emosional, dan seni. Pada perkembangan moral, dua subjek sudah mampu melakukan semua indikator perkembangan dengan baik, yaitu mengucapkan salam dan membalas salam dan menjaga kebersihan diri dari lingkungan. Sedangkan nilai agama yaitu, sudah mampu menirukan gerakan ibadah dengan urutan yang benar, dan mengenal agama yang dianutnya.

Pada aspek perkembangan fisik-motorik, dua subjek sudah mampu melakukan semua indikator perkembangan bagian motorik kasar terdapat tingkat pencapaian yaitu; naik turun tangga, berlari, melakukan gerakan tubuh secara koordinasi untuk melatih kelenturan dan melakukan permainan fifsik dengan aturan, motorik halus terdapat tingkat pencapaian yaitu; menggunting, menggambar, meniru bentuk dan mengepresikan diri melalui gerakan menggambar secara rinci, sedangkan kesehatan dan perilaku keselamatan tingkat pencapaian sudah tercapai seperti berat badan sesuai dengan tingkat usia, tinggi badan dan lingkar kepala sesuai dngan tingkat usia anak. 
Pada perkembangan kognitif ada dua subjek yang sudah mencapai semua indikator perkembangan dengan baik, namun pada subjek $\mathrm{N}$ terdapat dua indikator yang belum dicapai anak seperti; mengklasifikasikan benda berdasarkan warna, bentuk dan ukuran 93 variasi) anak perlu stimulasi mengenai 2 dan 3 variasi baik secara individu maupun kelompok. Pada perkembangan bahasa anak kedua subjek sudah mencapai semua indikator dan berkembang dengan tingkat pencapaian yang sudah tercapai dengan baik.

Perkembangan sosial emosional terdapat dua subjek yang sudah mencapai semua indikator perkembangan dengan baik namun pada subjek $\mathrm{N}$ ada beberapa indikator yang belum dicapai yaitu; mengenal perasaan sendiri dan mengoalnya secara sadar, mengatur diri sendiri dan menggunakan cara yang diterima secara sosial dalam menyelesaikan secara sosial dalam menyelesaikan masalah.

Kemudian pada perkembangan seni terdapat satu subjek yang belum mencapai tingkat perkembangan dengan baik yaitu; memainkan musik, instrumen, benda bersama teman dan menggunakan cara yang diterima secara sosial dalam menyelesaikan masalah. Anak masih perlu stimulasi orang tua agar aspek perkembangan yang belu dicapai dengan bisa tercapai dengan baik. Subjek kedua itu sudah mampu memainkan musik, instrumen, benda bersama teman dan mampu bermani drama sederhana walaupun masih perlu distimulasi.

\section{DAFTAR PUSTAKA}

Amelia N., Ali, \& Miranda. (2013). Peningkatan Aspek Perkembangan Nilai Agama dan Moral Anak Usia 5-6 Tahuin TK Al-Ikhlas Ketapang.

Filtri H., Sembiring AK. (2018). Perkembangan Kognitif Anak Usia 5-6 Tahun di Tinjau dari Tingkat Pendidikan Ibu di Paud Kasih Ibu Kecamatan Rumbai. Vol.1 No.2.

Harahap IS., (2017). Upaya meningkatkan perkembangan moral anak usia 5-6 tahun melalui metode bercerita di tk nurul ihsan ilmi medan tembung.

Intan Fazrin, Wildiana, Trianti, Baba, Amalia, \& Smaut. (2018). Pendidikan Kesehatan Deteksi Dini Tumbuh Kembang Pada Anak di Paud Lab School UNPGRI Kediri. Jurnal of Community Engagement in Healt. Vol.1 No. 2.

Khadijah., (2016). Pengembangan Kognitif Anak Usia Dini. Publishing Perdana Mulya Sarana.

Mudjiwati., (2014) Upaya Meningkatkan Kemampuan Social Emosional Anak Usia Dini, Repository.ump.ac.id.

Nugraha FE., (2017). Identifikasi Perkembangan MotoriK Halus Anak Usia 5-6 Tahun di Tk gugus III kecamatan piyungan Bantul.

Priyanto Sungeng Utuh, (2013). Pendidikan Musik untuk Anak Usia Dini.

64 NANAEKE - Indonesian Journal of Early Childhood Education, Vol. 2, No. 1, Juni 2019 
Retno DAP., (2017). Peningkatan Kemampuan Bahasa Ekspresif Anak USIA 5-6 Tahun Melalui Metode Outbound di TK Kemala Bhayangkari kecamatan Ngawen Kabupaten Blora. Universitas Negeri Semarang.

Sit Masganti. (2015). Psikologi Perkembangan Anak Usia Dini Jilid 1. Perdana Publishing. Jl. Suroso No. 16-A Medan.

Suryana D., (2016). Pendidikan Anak Usia Dini Stimulasi Aspek Perkembangan Anak. Kencana.

Suryaningrum C., Ingarianti, \& Anwar. (2016). Pengembangan Model Deteksi Dini Anak Berkebutuhan Khususs (ABK) Pada Tingkat Anak Usia Dini PAUD Di Kota Malang. Vol.4 No.1

Ulfa Miftakhul., (2018). Analisa Deteksi Dini dan Stimulasi Perkembangan Anak Usia Prasekolah. Jurnal IImiah IImu Kesehatan. Vol.6 No.3.

Wulandari R., Ichsan, \& Romadhon. (2016). Perbedaan Perkembangan Sosial Anak Usia 3-6 Tahun Dengan Pendidikan Usia Dini Dan Tanpa Pendidikan Usia Dini di Kecamatan Petarongan Jombang. Biomedika.Vol.8 No.1.

Yenny. 2017. Gambaran Perkembangan Motorik Anak Usia 5-6 Tahun yang Bermain Games gadge. Vol.1. 